\title{
Perbandingan Hematoma Pasca Kateterisasi Jantung Berdasarkan Penekanan Bantal Pasir dan Cold Pack
}

\author{
Eka Afrima Sari ${ }^{1}$, M.Z. Arifin ${ }^{2}$, Sari Fatimah ${ }^{3}$ \\ ${ }^{1,3}$ Fakultas Keperawatan, Universitas Padjadjaran \\ ${ }^{2}$ Departemen Bedah Saraf Fakultas Kedokteran, Unpad/RSUP. Dr. Hasan Sadikin \\ Email: ${ }^{1}$ e.afrima@unpad.ac.id
}

\begin{abstract}
ABSTRAK
Kateterisasi jantung merupakan prosedur untuk mendiagnosis dan/atau mengevaluasi arteri koroner. Pada akhir prosedur, dilakukan pelepasan femoral sheath dan penekanan manual maupun mekanik pada arteri femoralis untuk mengontrol perdarahan hingga tercapai hemostasis. Teknik penekanan yang tidak adekuat pada sisi akses arteri setelah kateterisasi jantung merupakan salah satu penyebab terjadinya hematoma. Ditemukan kejadian hematoma pada pasien pasca kateterisasi jantung yang timbul beberapa waktu setelah penekanan mekanik bantal pasir. Penelitian ini bertujuan untuk membandingkan ukuran hematoma dalam waktu 24 jam pasca kateterisasi jantung berdasarkan penekanan mekanik bantal pasir dan cold pack. Penelitian ini merupakan penelitian komparatif dengan pendekatan after-only non-equivalent control group design. Subjek penelitian adalah 20 orang pasien pasca kateterisasi jantung yang dibagi menjadi kelompok eksperimen dengan penekanan mekanik cold pack selama 20 menit setelah pelepasan femoral sheath dan kelompok kontrol dengan penekanan mekanik bantal pasir 2,5 Kg selama 6 jam setelah pelepasan femoral sheath. Kejadian hematoma dilihat setelah penekanan manual, penekanan mekanik, dan setiap jam selama 24 jam. Perbedaan kejadian hematoma dilihat dengan menggunakan uji Mann-Whitney. Hasil penelitian menunjukkan bahwa tidak terdapat perbedaan bermakna ukuran hematoma setelah penekanan manual, penekanan mekanik dan setiap jam dalam waktu 24 jam pada pasien pasca kateterisasi jantung yang menggunakan bantal pasir maupun cold pack $(\rho>0,05)$. Pada kelompok eksperimen ukuran hematoma mengecil di akhir jam ke-24 dan pada kelompok kontrol ukuran hematoma membesar di akhir jam ke-24. Penggunaan penekanan mekanik cold pack dapat mengurangi risiko hematoma sebagaimana bantal pasir, sehingga cold pack dapat digunakan sebagai pilihan alat tekan mekanik pada pasien pasca kateterisasi jantung.
\end{abstract}

Kata kunci: Bantal pasir, cold pack, hematoma, kateterisasi jantung.

\begin{abstract}
Cardiac catheterization is a procedure to diagnose and/or evaluate coronary arteries. At the end of procedure, performed manual and mechanical compression on the femoral artery to control bleeding until homeostasis is achieved. Inadequate compression techniques on the arterial access after cardiac catheterization is one of the causes of hematoma. Found in hematoma incidence in patients after cardiac cathetherization that arise after mechanical compression using sandbags. The purpose of this study was to compare the size of the hematoma within 24 hours after cardiac catheterization using sandbags and cold pack mechanical compression. The study design was a comparative study with after-only non-equivalent control group design. Research subjects included of 20 after cardiac catheterization patients were divided into an experimental group with cold pack mechanical compression for 20 minutes after femoral sheath release and control group with sandbags mechanical compression for 6 hours after femoral sheath release. Incidence of hematoma was observed after manual compression, mechanical compression, and every hour for 24 hours. Mann-Whitney test was used to see the difference the incidence of hematoma of both of groups. The results showed no significant difference in the size of the hematoma after manual compression, mechanical compression,
\end{abstract}


and every hour within 24 hours after cardiac catheterization in both of groups ( $\rho>0.05)$. But the size of the hematoma in the end of observation time was smaller in experiment group, and bigger in the control group. The use ofcold pack mechanical compressions could reduce the risk of hematoma as well as sandbags. Thus, cold pack could be used as an alternative mechanical compression tool in patients with post cardiac catheterization.

Keywords: Cardiac catheterization, cold pack, hematoma, sandbags

\section{PENDAHULUAN}

Penyakit jantung adalah salah satu penyakit yang menyebabkan kematian terbanyak di Indonesia. Berdasarkan data tabulasi dasar di rumah sakit, penyakit jantung merupakan penyebab kematian ketiga setelah stroke dan cedera intrakranial dengan jumlah kematian 2.484 (2,67\%) (Direktorat Jenderal Pengendalian Penyakit \& Penyehatan Lingkungan Republik Indonesia [PP \& PL RI], 2009). Berdasarkan data World Health Report (2004), penyakit jantung koroner merupakan penyebab kematian paling besar (7,208 juta) diantara penyakit jantung lainnya (16,733 juta). Deteksi plak aterosklerosis dengan angiografi koroner merupakan "gold standard" pada penyakit jantung koroner (Grossman, 2000). Kateterisasi jantung memiliki tingkat ketepatan paling tinggi $(96 \%-99 \%)$ untuk mendeteksi adanya kelainan pada jantung terutama penyakit jantung koroner (Lindsay \& Pinnow, 2000 sebagaimana dikutip Osborn et al., 2010).

Pada akhir prosedur kateterisasi, dilakukan pelepasan femoral sheath dan penekanan (baik penekanan manual maupun penekanan mekanik) pada arteri femoralis untuk mengontrol perdarahan hingga tercapai hemostasis. Teknik pencapaian hemostasis ini mempengaruhi timbulnya komplikasi vaskular (Jones \& Mccutcheon, 2002). Hematoma merupakan salah satu komplikasi vaskular yang paling banyak dilaporkan dan berpotensi menimbulkan komplikasi serius setelah tindakan kateterisasi jantung melalui arteri femoralis (Lundin, Sargent, \& Burke, 1998). Hematoma terjadi karena area akses penusukan tidak tertutup dengan baik dan terdapat akumulasi darah disekitar jaringan. Ukuran hematoma yang besar dapat menyebabkan ketidaknyamanan pada pasien dan berpotensi untuk berkembang menjadi false aneurysms. Didapatkan beberapa kejadian hematoma pada pasien pasca kateterisasi jantung yang timbul beberapa waktu setelah selesai penekanan mekanik, bahkan ada yang timbul keesokan harinya.

Faktor risiko terjadinya komplikasi vaskular ini adalah karakteristik pasien seperti usia lanjut, perempuan, dan berat badan rendah atau obesitas; obat-obat yang digunakan selama kateterisasi seperti terapi trombolitik, terapi heparin sebelum prosedur dilakukan, terapi heparin $>85$ unit/ $\mathrm{Kg}$, dan clopidogrel atau glikoprotein IIb/ IIIa receptor inhibitor; tipe prosedur seperti prosedur tindakan yang lama, lama sheath dilepas, ukuran sheath $\geq 7 \mathrm{~F}$, penusukan pada arteri femoralis sebelumnya, penusukan arteri femoralis diatas ligamen inguinal, dan kesulitan dalam melakukan penekanan pada pasien obesitas; penyakit penyerta seperti hipertensi, diabetes, perdarahan gastrointestinal, atrial fibrilasi, syok kardiogenik, infark miokard akut, ventrikular takikardi atau fibrilasi, dan gagal ginjal atau peningkatan level kreatinin; dan penggunaan penekanan manual dan/ atau mekanik pada sisi akses kateterisasi (Lins, Guffey, Vanriper, Kline-rogers, \& Guffey, 2006 dan Patients Safety Advisory, 2007).

Untuk mengurangi risiko timbulnya komplikasi vaskular seperti hematoma ini, dilakukan manajemen pada pasien pasca kateterisasi jantung yang bertujuan untuk mencapai hemostasis vaskular pada sisi akses kateterisasi melalui penekanan manual dan/ 
atau mekanik (Ying et al., 2008). Penekanan manual ini dilakukan dengan menekan arteri femoralis selama 20 menit atau lebih untuk mengontrol perdarahan hingga terjadi koagulasi dan merupakan standar tindakan setelah pelepasan sheath (Patients Safety Advisory, 2007). Seperti penekanan manual, penekanan mekanik juga efektif dalam mencapai hemostasis pada arteri femoralis setelah kateterisasi jantung (Patients Safety Advisory, 2007 dan Simon et al., 1998). Pada penekanan mekanik diperlukan alat seperti bantal pasir atau cold pack.

Penelitian mengenai penggunaan bantal pasir ini dilakukan oleh Yilmaz, Gurgun, dan Dramali (2007) pada pasien yang menjalani prosedur invasif jantung dengan mengevaluasi penggunaan bantal pasir dan perubahan posisi pasien terhadap kejadian komplikasi vaskular dan back pain. Hasil penelitian menunjukkan bahwa bantal pasir tidak efektif dalam menurunkan kejadian komplikasi vaskular dimana tidak terdapat perbedaan signifikan kejadian komplikasi vaskular pada kelompok yang menggunakan bantal pasir dengan kelompok yang tidak menggunakan bantal pasir. Penelitian lain yang dilakukan oleh Christensen et al., (1998) dan Juran et al., (1999) menunjukkan bahwa bantal pasir tidak efektif dalam menurunkan kejadian komplikasi vaskular dan perdarahan. Bantal pasir juga meningkatkan ketidaknyamanan pasien (B Christensen et al., 1994). Penekanan mekanik dengan menggunakan bantal pasir merupakan Standar Operasional Prosedur (SOP) dalam menangani pasien pasca kateterisasi jantung di RSUP Dr. Hasan Sadikin Bandung.

Sedangkan penelitian mengenai penggunaan cold pack dilakukan oleh (King, Philpott, \& Leary, 2008) pada pasien pasca kateterisasi jantung yang bertujuan untuk mengidentifikasi manajemen hemotoma femoral yang optimal dengan membandingkan efektivitas penekanan mekanik menggunakan bantal pasir dan cold pack dalam penanganan femoral hematoma.
Penelitian ini dilakukan pada pasien yang sudah memiliki hematoma sebelumnya, hematoma diukur setiap 30 menit selama 3 jam. Hasil penelitian menujukkan bahwa vasokonstriksi yang dihasilkan oleh cold pack lebih efektif dalam mengurangi hematoma dibandingkan dengan bantal pasir. Penelitian yang dilakukan oleh Karen (2009) membandingkan penekanan menggunakan bantal pasir dengan cold pack, hasil penelitian menunjukkan bahwa secara signifikan cold pack mengurangi kejadian hematoma pada pasien dibandingkan dengan bantal pasir dan pasien melaporkan bahwa penggunaan cold pack dirasakan lebih nyaman (Karen, 2009 sebagaimana dikutip Manik, 2012).

Penelitian lain dilakukan oleh Manik (2012) pada pasien pasca kateterisasi jantung yang melihat perbedaan kejadian komplikasi vaskuler lokal dan neuropati femoral pada penekanan mekanik menggunakan cold pack selama 20 menit dengan penekanan mekanik menggunakan bantal pasir seberat $2,5 \mathrm{Kg}$ selama 1 jam. Kejadian komplikasi vaskuler lokal dan neuropati femoral dilihat setelah penekanan mekanik, yaitu setelah 1 jam untuk penekanan menggunakan bantal pasir dan setelah 20 menit untuk penekanan mengunakan cold pack. Hasil penelitian menunjukkan bahwa tidak terdapat perbedaan signifikan pada kelompok yang menggunakan bantal pasir maupun cold pack terhadap kejadian komplikasi vaskuler lokal dan neuropati femoral (Manik, 2012).

Cold pack menggunakan suhu yang dingin dalam menangani injuri. Perubahan pada suhu memiliki pengaruh pada permukaan jaringan tubuh seperti pengurangan nyeri, relaksasi otot, perubahan pembuluh darah, dan pengaruh pada jaringan konektif. Pada suhu yang dingin, sensasi nyeri dihambat melalui pengurangan kecepatan impuls yang dikonduksikan oleh serabutserabut saraf. Suhu dingin juga menyebabkan terjadinya vasokonstriksi pembuluh darah arteri dan vena dengan stimulasi pada otototot halus pada lapisan pembuluh darah. 
Vasokonstriksi ini menyebabkan menurunnya perdarahan dan pembengkakan pada jaringan yang mengalami injuri (Wnorowsky, 2011).

Penelitian yang dilakukan oleh Manik (2012) mengenai penggunaan cold pack selama 20 menit dan bantal pasir seberat 2,5 $\mathrm{Kg}$ selama 1 jam dalam penekanan mekanik hanya melihat kejadian komplikasi vaskuler lokal dan neuropati femoral sesaat setelah penekanan selesai dilakukan, yaitu setelah 20 menit pada penekanan dengan menggunakan cold pack dan setelah 1 jam pada penekanan dengan menggunakan bantal pasir. Untuk kejadian beberapa jam setelah penekanan tidak diobservasi dalam penelitian.

Penelitian mengenai penggunaan cold pack ini sudah pernah dilakukan pada pasien yang sudah memiliki hematoma sebelumnya, juga sudah dilakukan pada pasien yang belum memiliki hematoma sebelumnya. Untuk pemantauan hematoma, sudah dilakukan setiap 30 menit selama 3 jam dan setelah penekanan selesai dilakukan. Untuk melihat kejadian hematoma dalam waktu 24 jam belum pernah dilakukan.

Meskipun penelitian mengenai penggunaan cold pack ini sudah pernah dilakukan diluar negeri, di Indonesia sendiri khususnya RSUP Dr. Hasan Sadikin masih menggunakan bantal pasir sebagai SOP untuk penekanan mekanik pasca kateterisasi jantung. Terdapatnya perbedaan teknologi dalam pelaksanaan tindakan kateterisasi jantung didalam maupun diluar negeri, mendasari penulis untuk melakukan penelitian mengenai penggunaan cold pack sebagai penekanan mekanik dengan melihat ukuran hematoma dalam waktu 24 jam, yaitu mendekatkan hasil penelitian yang terdapat diluar negeri agar evidence nya sesuai dengan keadaan di Indonesia seperti dalam hal teknologi dan tenaga kesehatan. Di RSUP Dr. Hasan Sadikin sendiri sudah pernah dilakukan penelitian mengenai penggunaan cold pack terhadap kejadian komplikasi vaskuler lokal dan neuropati femoral, komplikasi dilihat sesaat setelah penekanan selesai dilakukan, untuk pemantauan beberapa waktu setelah penekanan tidak dilakukan. Melihat dari hasil studi pendahuluan menunjukkan bahwa hematoma muncul beberapa waktu setelah selesai penekanan mekanik bahkan ada yang timbul keesokan harinya, serta waktu terjadinya hematoma menurut Kern et al (1990) yaitu dari waktu penekanan hingga ambulasi yang disebut early hematoma dan dari waktu ambulasi hingga $24-72$ jam setelah penekanan yang disebut late hematoma.

Peneliti tertarik untuk melihat ukuran hematoma dari waktu ke waktu setelah pelepasan femoral sheath yaitu setelah penekanan manual dan mekanik serta setiap satu jam selama 24 jam dengan menggunakan jenis penekanan mekanik yang sama yaitu cold pack selama 20 menit. Pemantauan dan pengukuran hematoma dari jam ke jam selama 24 jam ini bertujuan untuk melihat perkembangan hematoma dari waktu ke waktu, sehingga dapat diketahui hematoma muncul pada jam ke berapa dan kecenderungan ukuran hematoma tersebut tetap, semakin bertambah atau berkurang. Pengukuran yang dilakukan setelah penekanan manual ini dilakukan untuk melihat apakah hematoma tersebut timbul akibat penekanan manual atau akibat jenis penekanan mekanik yang digunakan. Untuk penggunaan bantal pasir $2,5 \mathrm{Kg}$ dilakukan selama 6 jam karena merupakan SOP yang terdapat diruangan untuk perawatan pasien pasca kateterisasi jantung.

Tujuan umum penelitian ini adalah mengidentifikasi perbandingan ukuran hematoma pasca pelepasan femoral sheath kateterisasi jantung berdasarkan penekanan mekanik bantal pasir dan cold pack. Adapun tujuan khususnya adalah mengidentifikasi ukuran hematoma dalam waktu 24 jam pasca pelepasan femoral sheath kateterisasi jantung berdasarkan penekanan mekanik bantal pasir dan cold pack, mengidentifikasi waktu munculnya hematoma pasca pelepasan femoral sheath kateterisasi jantung 
berdasarkan penekanan mekanik bantal pasir dan cold pack, dan membanding ukuran hematoma dalam 24 jam pasca pelepasan femoral sheath kateterisasi jantung berdasarkan penekanan mekanik bantal pasir dan cold pack.

\section{METODE}

Jenis penelitian ini berupa penelitian komparatif dengan pendekatan after-only non-equivalent control group design. Subjek penelitian terdiri dari 20 orang pasien pasca kateterisasi jantung melalui arteri femoralis yang dibagi menjadi kelompok eksperimen dan kelompok kontrol. Kelompok eksperimen menggunakan penekanan mekanik cold pack selama 20 menit setelah pelepasan femoral sheath dan kelompok kontrol menggunakan penekanan mekanik bantal pasir seberat 2,5 Kg selama 6 jam setelah pelepasan femoral sheath. Kejadian hematoma diobservasi setelah penekanan manual, setelah penekanan mekanik, dan setiap jam selama 24 jam.

Teknik pengumpulan data pada penelitian ini diakukan beberapa langkah. Langkah pertama dengan pengumpulan data karakteristik pasien yang terdiri dari usia, jenis kelamin, diagnosis medis, penggunaan obat-obatan anti koagulan dan trombolitik, BMI, ukuran sheath, prosedur yang dilakukan, dan tekanan darah. Setelah itu dilakukan pelepasan femoral sheath dengan penekanan manual, kemudian dilakukan penekanan mekanik menggunakan cold pack selama 20 menit pada kelompok eksperimen dam bantal pasir 2,5 $\mathrm{Kg}$ selama 6 jam pada kelompok kontrol. Pasien kemudian bed rest selama 6 jam dan diobservasi setiap jam selama 24 jam untuk melihat kejadian hematoma dengan menggunakan penggaris yang dibersihkan dengan alkohol terlebih dahulu dan observer yang mengukur menggunakan sarung tangan. Jika dalam waktu observasi subjek penelitian tidur, maka tidak dilakukan pengukuran hematoma. Untuk data yang kosong selama subjek penelitian tidur, disesuaikan dengan diameter hematoma sebelum pasien tidur.

Analisis univariat dilakukan untuk melihat distribusi frekuensi subjek penelitian berdasarkan karakteristiknya dan ukuran hematoma pada masing-masing kelompok. Adapun karakteristik subjek penelitian yang dianalisis adalah usia, jenis kelamin, Indeks Massa Tubuh (IMT), ukuran sheath, dan tekanan darah. Distribusi frekuensi ukuran hematoma dikelompokkan menjadi hematoma kecil (diameter $<2,5 \mathrm{~cm}$ ), hematoma sedang (diameter 2,5 $-5 \mathrm{~cm}$ ), dan hematoma besar $(>5 \mathrm{~cm})$. Data dianalisis dengan distribusi frekuensi.

Analisis bivariat bertujuan untuk melihat perbedaan ukuran hematoma pada kelompok eksperimen dan kelompok kontrol. Dalam analisis bivariat, yang di analisis adalah angka diameter hematoma masing-masing subjek penelitian pada kedua kelompok. Setelah dilakukan uji normalitas data dengan menggunakan Uji Kolmogorov-Smirnov didapatkan bahwa $\rho<0,05$ sehingga data tidak terdistribusi normal, maka uji beda dilakukan menggunakan Uji Mann-Whitney

\section{HASIL PENELITIAN}

Subjek penelitian terdiri dari 20 orang pasien (kelompok kontrol dan intervensi) pasca kateterisasi jantung melalui arteri femoralis. Dari 20 orang pasien tersebut, yang menjalani kateterisasi jantung dengan tujuan diagnostik sebanyak 5 orang, tujuan intervensi 3 orang, dan tujuan diagnostik sekaligus intervensi 12 orang. Karakteristik subjek penelitian dilihat berdasarkan usia, jenis kelamin, Indeks Massa Tubuh (IMT), ukuran sheath yang digunakan, dan tekanan darah sebelum pelepasan femoral sheath. Karakteristik subjek penelitian disajikan pada tabel 1 dibawah ini: 
Tabel 1. Karakteristik Subjek Penelitian pada Kelompok Kontrol dan Eksperimen

\begin{tabular}{|c|c|c|c|c|}
\hline \multirow{2}{*}{ Variabel } & \multicolumn{2}{|c|}{ Kontrol $(n=10)$} & \multicolumn{2}{|c|}{ Eksperimen $(n=10)$} \\
\hline & $\mathbf{f}$ & $\%$ & f & $\%$ \\
\hline Usia (dalam tahun) & \multicolumn{2}{|c|}{$61(37-72)^{\mathrm{a}}$} & \multicolumn{2}{|c|}{$55,5(44-72)^{\mathrm{a}}$} \\
\hline Dewasa Awal $(<45)$ & 2 & 20 & 1 & 10 \\
\hline Dewasa Pertengahan $(45-59)$ & 2 & 20 & 5 & 50 \\
\hline Usia Lanjut $(\geq 60)$ & 6 & 60 & 4 & 40 \\
\hline \multicolumn{5}{|l|}{ Jenis Kelamin } \\
\hline Laki-Laki & 8 & 80 & 7 & 70 \\
\hline Perempuan & 2 & 20 & 3 & 30 \\
\hline Indeks Massa Tubuh (IMT) & \multicolumn{2}{|c|}{$26,58(19,53-31,25)^{\mathrm{a}}$} & \multicolumn{2}{|c|}{$28,06(22,77-32,03)^{\mathrm{a}}$} \\
\hline Normal $(18,50-24,99)$ & 3 & 30 & 3 & 30 \\
\hline Berat Badan Lebih $(\geq 25)$ & 5 & 50 & 6 & 60 \\
\hline Obesitas $(\geq 30)$ & 2 & 20 & 1 & 10 \\
\hline \multicolumn{5}{|l|}{ Ukuran Sheath } \\
\hline 6 French & 9 & 90 & 9 & 90 \\
\hline 7 French & 1 & 10 & 1 & 10 \\
\hline \multicolumn{5}{|l|}{ Tekanan Darah } \\
\hline Normal & 2 & 20 & 2 & 20 \\
\hline Pre Hipertensi & 3 & 30 & 7 & 70 \\
\hline Hipertensi Derajat 1 & 3 & 30 & 1 & 10 \\
\hline Hipertensi Derajat 2 & 2 & 20 & 0 & 0 \\
\hline
\end{tabular}

a. Nilai median dan nilai minimum-

\section{maksimum}

Pengukuran hematoma dilakukan sesaat setelah penekanan manual dan mekanik serta setiap jam selama 24 jam. Perubahan mean ukuran hematoma subjek penelitian dalam waktu 24 jam setelah pelepasan femoral sheath pada kelompok kontrol dan eksperimen dapat dilihat pada gambar 1 dibawah ini:

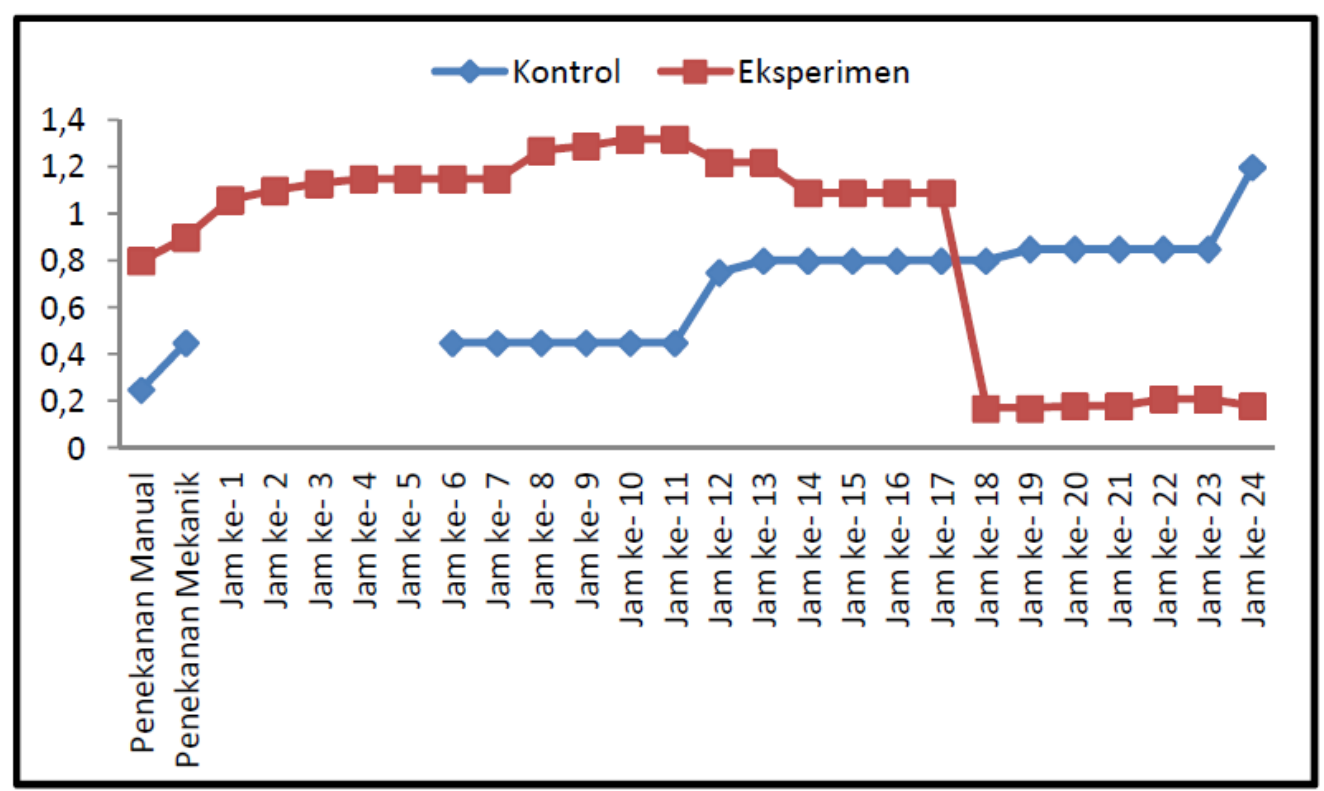

Gambar 1. Perubahan Ukuran Hematoma Kelompok Eksperimen dan Kontrol dalam Waktu 24 Jam

Gambar 1 menunjukkan bahwa pada kelompok kontrol ukuran hematoma bertambah besar hingga akhir jam ke- 24 .
Sebaliknya, pada kelompok eksperimen ukuran hematoma terus mengecil hingga akhir jam ke- 24 . 
Analisis bivariat terhadap kejadian hematoma dalam waktu 24 jam pada kelompok kontrol dan eksperimen disajikan pada tabel 2 dibawah ini:

Tabel 2. Perbedaan Ukuran Diameter Hematoma dalam centimeter (cm) pada Kelompok Kontrol dan Eksperimen dalam Waktu 24 Jam

\begin{tabular}{|c|c|c|c|c|}
\hline \multirow{2}{*}{ Waktu Pengukuran } & \multicolumn{2}{|c|}{ Median (Nilai Min - Maks) } & \multirow{2}{*}{$\mathbf{Z}_{\mathbf{M}-\mathbf{W}}$} & \multirow{2}{*}{ Nilai $\rho$} \\
\hline & Kontrol & Eksperimen & & \\
\hline Penekanan Manual & $0(0-1)$ & $0(0-8)$ & $-0,920$ & 0,358 \\
\hline Penekanan Mekanik & $0(0-2)$ & $0(0-9)$ & $-1,290$ & 0,196 \\
\hline $\begin{array}{l}\text { Sebelum Mobilisasi } \\
\text { (Jam ke- 6) }\end{array}$ & $0(0-2)$ & $0(0-9,5)$ & $-0,266$ & 0,790 \\
\hline Jam ke- $7-9$ & $0(0-2)$ & $0(0-9,5)$ & $-0,266$ & 0,790 \\
\hline Jam ke- $10-11$ & $0(0-2)$ & $0(0-10)$ & $-0,171$ & 0,864 \\
\hline Jam ke- $12-13$ & $0(0-5)$ & $0(0-10)$ & $-0,266$ & 0,790 \\
\hline Jam ke- $14-17$ & $0(0-5)$ & $0(0-9)$ & $-0,355$ & 0,723 \\
\hline Jam ke- $18-19$ & $0(0-5)$ & $0(0-1,1)$ & $-1,025$ & 0,305 \\
\hline Jam ke- $20-21$ & $0(0-5)$ & $0(0-1,2)$ & $-1,119$ & 0,263 \\
\hline Jam ke- $22-23$ & $0(0-5)$ & $0(0-1,5)$ & $-1,073$ & 0,283 \\
\hline Jam ke- 24 & $0(0-6)$ & $0(0-1,2)$ & $-1,597$ & 0,110 \\
\hline
\end{tabular}

Pada tabel 2 analisis bivariat terhadap kejadian hematoma dalam waktu 24 jam pada kelompok kontrol dan eksperimen menunjukkan bahwa tidak terdapat perbedaan ukuran hematoma setelah penekanan manual, setelah penekanan mekanik, dan setiap jam selama 24 jam pada kelompok kontrol dan eksperimen $(\rho>0,05)$. Pada kelompok kontrol, terdapat peningkatan nilai maksimum diameter hematoma dari mulai penekanan manual hingga observasi pada akhir jam ke24. Sedangkan pada kelompok eksperimen, pada awalnya terdapat peningkatan nilai maksimum diameter hematoma namun kemudian terjadi penurunan hingga observasi pada akhir jam ke- 24 .

\section{PEMBAHASAN}

Komplikasi vaskular merupakan komplikasi minor dan komplikasi pada area akses kateterisasi yang paling sering terjadi pasca kateterisasi jantung seperti hematoma (Patients Safety Advisory, 2007). Hematoma merupakan salah satu komplikasi vaskular yang paling banyak dilaporkan dan berpotensi menimbulkan komplikasi serius setelah tindakan kateterisasi jantung melalui arteri femoralis (Lundin et al., 1998). Hematoma ini terjadi karena area akses penusukan tidak tertutup dengan baik dan terdapat akumulasi darah disekitar jaringan. Hematoma yang besar dapat menyebabkan ketidaknyamanan pada pasien dan berpotensi untuk berkembang menjadi false aneurysms.

Faktor risiko terjadinya komplikasi vaskular ini adalah karakteristik pasien seperti usia lanjut, perempuan, dan berat badan rendah atau obesitas; obat-obat yang digunakan selama kateterisasi seperti terapi trombolitik, terapi heparin sebelum prosedur dilakukan, terapi heparin $>85$ unit/ $\mathrm{Kg}$, dan clopidogrel atau glikoprotein IIb/IIIa receptor inhibitor; tipe prosedur seperti prosedur tindakan yang lama, lama sheath dilepas, ukuran sheath $\geq 7 \mathrm{~F}$, penusukan pada arteri femoralis sebelumnya, penusukan arteri femoralis diatas ligamen inguinal, dan kesulitan dalam melakukan penekanan pada pasien obesitas; penyakit penyerta seperti hipertensi, diabetes, perdarahan gastrointestinal, atrial fibrilasi, syok kardiogenik, infark miokard akut, ventikular takikardi atau fibrilasi, dan gagal ginjal atau peningkatan level kreatinin; dan penggunaan penekanan manual dan/ atau mekanik pada sisi akses kateterisasi (Lins, Guffey, Vanriper, Kline-rogers, \& Guffey, 2006; Patients Safety Advisory, 2007).

Usia subjek penelitian dalam penelitian ini berada dalam rentang usia lanjut $(\geq 60$ 
tahun), dewasa pertengahan ( $45-59$ tahun), dan dewasa awal ( $<45$ tahun). Sebagian besar subjek penelitian berada pada rentang usia lanjut, dalam hal ini, usia lanjut merupakan salah satu faktor risiko terjadinya komplikasi vaskular pada pasien pasca kateterisasi jantung (Lins et al., 2006; Patients Safety Advisory, 2007). Rata-rata usia subjek penelitian adalah 59 tahun dengan SD 10,38. Subjek penelitian termuda berusia 37 tahun dan tertua berusia 72 tahun. Hal ini menunjukan bahwa kejadian penyakit jantung koroner juga dapat terjadi pada usia muda. Penelitian yang dilakukan di Semarang tahun 2008 menunjukan bahwa faktor resiko meningkatnya angka kejadian penyakit jantung koroner pada usia $\leq 45$ tahun adalah dislipidemia, kebiasaan merokok, adanya penyakit Diabetes Melitus (DM), dan faktor turunan DM dalam keluarga (Supriyono, 2008).

Penelitian lain menunjukan kejadian injuri dan perdarahan pada pembuluh darah koroner lebih sering pada perempuan dari pada laki-laki. Perbedaan ini terjadi pada usia $\leq 55$ tahun (Argulian et al., 2006). Perempuan dengan usia $\leq 55$ tahun berada pada periode pra menopause, hal ini memungkinkan untuk meningkatkan risiko komplikasi vaskular dibandingkan dengan laki-laki dilihat dari status estrogen. Estrogen meningkatkan level berbagai faktor koagulasi dan penanda inflamasi serta mempengaruhi fungsi pembuluh darah endotelial dan reaksinya terhadap faktor sirkulasi vasoaktif (Miller, Lewis, \& Barber, 1999; Rubanyi, Johns, \& Kauser, 2002; Cushman, 2002). Sebagian besar dari efek ini mungkin bervariasi pada level pasien dan mungkin sulit untuk diprediksi (Rosendaal, Helmerhorst, \& Vandenbroucke, 2002). Namun, estrogen mungkin memainkan peran dalam meningkatkan kerentanan dari beberapa wanita muda ( $\leq 55$ tahun) untuk cedera vaskular.

Selain itu, perempuan pra menopause dengan penyakit jantung koroner mungkin memiliki respon abnomal pembuluh darah koroner dengan estrogen akibat kelainan kuantitatif atau kualitatif dari reseptor pembuluh darah estrogen (Losordo, Kearney, Kim, Jekanowski, \& Isner, 1994). Perbedaan jenis kelamin juga menyebabkan variasi outcomes pasien pasca kateterisasi jantung (PCI) karena pada perempuan memiliki diameter pembuluh darah yang kecil yang meningkatkan komplikasi vaskular periprosedural pada sisi akses kateter dan pembuluh koroner selama tindakan (Argulian et al., 2006).

Merujuk pada sumber diatas, pada penelitian ini jumlah subjek penelitian lakilaki lebih banyak daripada perempuan sehingga mungkin mempengaruhi hasil penelitian kejadian hematoma yang sebagian besar berukuran kecil. Adapun satu orang subjek penelitian yang memiliki hematoma besar pada kelompok eksperimen adalah perempuan.

Jika dilihat berdasarkan IMT, sebagian besar subjek penelitian berada pada rentang berat badan lebih dan obesitas. Hal ini berpengaruh pada penekanan manual yang dilakukan setelah pelepasan femoral sheath, dimana akan membutuhkan penekanan yang lebih kuat dibandingkan dengan pasien dengan berat badan normal. Tekanan yang tidak konsisten pada saat penekanan karena kelelahan pada lengan saat penekanan dapat menyebabkan terjadinya hematoma dan/ atau trombus (Jones \& Mccutcheon, 2002). Salah satu faktor risiko terjadinya komplikasi vaskular pada pasien pasca kateterisasi jantung adalah obesitas (Lins et al., 2006; Patients Safety Advisory, 2007). Dalam penelitian ini, pada 2 orang subjek penelitian yang memiliki IMT pada rentang berat badan lebih dan 1 orang subjek penelitian dengan obesitas ditemukan adanya hematoma kecil setelah penekanan manual.

Tekanan darah sebagian besar subjek penelitian berada pada kategori pre hipertensi, kemudian hipertensi derajat 1 , dan hipertensi derajat 2. Faktor lain yang dapat 
meningkatkan risiko pengembangan hematoma yaitu tekanan darah sistolik $>160$ mmHg. Komplikasi vaskular lebih umum terjadi pada pasien dengan hipertensi, gangguan pembekuan darah, dan perdarahan yang ditemukan pada area akses sebelum pelepasan sheath atau ambulasi (Woods et al., 2010). Pada penelitian ini, ditemukan kejadian hematoma kecil pada 2 orang subjek penelitian dengan hipertensi derajat 2 pada kelompok kontrol.

Penggunaan ukuran sheath $\geq 7$ french juga merupakan salah satu faktor risiko terjadinya komplikasi vaskular pada pasien pasca kateterisasi jantung. Pada penelitian ini, terdapat 2 orang subjek penelitian yang menggunakan ukuran sheath 7 french dan pada salah satunya terdapat hematoma kecil, dimana subjek penelitian yang terdapat hematoma ini berusia lanjut dengan obesitas. Sehingga terdapat beberapa faktor risiko untuk terjadinya pada hematoma.

Pada penelitian ini, faktor-faktor yang dapat mempengaruhi kejadian hematoma pada subjek penelitian dikontrol dengan melakukan uji homogenitas kelompok kontrol dan eksperimen. Hasil uji homogenitas menunjukan bahwa karakteristik subjek kelompok kontrol dan eksperimen adalah tidak berbeda secara bermakna.

Salah satu manajemen pasien pasca kateterisasi jantung adalah penggunaan penekanan manual dan/ atau mekanik yang bertujuan untuk mencapai hemostasis vaskular pada sisi akses kateterisasi sehingga dapat mengurangi risiko komplikasi vaskular seperti hematoma (Ying et al., 2008). Pada akhir prosedur kateterisasi, dilakukan pelepasan femoral sheath dan dilakukan penekanan pada arteri femoralis untuk mengontrol perdarahan hingga tercapai hemostasis. Teknik pencapaian hemostasis optimal setelah pelepasan sheath di arteri femoralis mempengaruhi timbulnya komplikasi vaskular (Jones \& Mccutcheon, 2002). Menurut Babu et al., penekanan yang tidak adekuat pada sisi akses arteri setelah kateterisasi jantung merupakan salah satu penyebab terjadinya komplikasi vaskular (Simon et al., 1998).

Penelitian ini bertujuan membandingkan ukuran hematoma dalam waktu 24 jam pada pasien pasca kateterisasi jantung dengan menggunakan penekanan mekanik bantal pasir seberat 2,5 $\mathrm{Kg}$ selama 6 jam (kelompok kontrol) dengan cold pack selama 20 menit (kelompok eksperimen). Penggunaan bantal pasir sebagai penekanan mekanik merupakan Standar Operasional Prosedur (SOP) untuk penanganan pasien pasca kateterisasi. Pengukuran kejadian hematoma pada penelitian ini dilakukan setelah penekanan manual, setelah penekanan mekanik menggunakan cold pack (kelompok eksperimen) dan bantal pasir (kelompok kontrol), selanjutnya setiap jam selama 24 jam untuk melihat perkembangan hematoma dari waktu ke waktu..

Setelah pelepasan femoral sheath, dilakukan penekanan manual selama 20 menit pada arteri femoralis untuk menghentikan perdarahan dan memungkinkan pembentukan bekuan (clot) (Hamel, 2009). Setelah penekanan manual ini, timbul hematoma kecil pada 3 orang subjek penelitian (kelompok kontrol) dan hematoma besar pada 1 orang subjek penelitian (kelompok eksperimen). Penekanan manual yang dilakukan oleh perawat ini dapat berlangsung lama untuk mencapai terjadinya homeostasis, sehingga bisa terjadi kelelahan pada lengan. Tekanan yang tidak konsisten karena kelelahan pada lengan saat penekanan dapat menyebabkan terjadinya hematoma dan/ atau trombus (Jones \& McCutcheon, 2002). Pengalaman orang yang melakukan penekanan manual dan IMT subjek penelitian juga mempengaruhi timbulnya hematoma. Terdapat kesulitan dalam melakukan penekanan pada pasien dengan obesitas, sehingga berisiko untuk timbulnya komplikasi vaskular (Lins et al., 2006). Dalam penelitian ini, timbul hematoma kecil setelah penekanan manual pada salah 
satu subjek penelitian yang berada dalam kategori obesitas (IMT 31,25).

Pada kelompok kontrol yang menggunakan penekanan mekanik bantal pasir seberat $2,5 \mathrm{Kg}$ selama 6 jam, setelah selesai penekanan timbul hematoma baru pada 1 orang subjek penelitian dan pada 3 orang subjek penelitian terdapat penambahan ukuran hematoma. Penambahan ukuran ini dilihat dari diameter hematoma sebelumnya yang timbul akibat penekanan manual. Setelah penekanan mekanik, pasien diobservasi setiap jam selama 24 jam untuk kejadian hematoma. Pada jam ke- 7 sampai dengan jam ke- 12 , terdapat 3 orang subjek penelitian dengan ukuran hematoma sama dengan sebelumnya dan 1 orang mengalami penambahan ukuran hematoma pada jam ke12. Pada jam ke- 13 sampai dengan jam ke24 , terdapat 2 orang subjek penelitian yang mengalami penambahan ukuran hematoma pada jam ke- 24,1 orang mengalami penambahan ukuran hematoma pada jam ke13 dan ke- 24, dan 1 orang mengalami penambahan ukuran hematoma pada jam ke19 dan ke- 24. Pada akhir jam ke- 24 ini, kelompok kontrol mengalami penambahan ukuran hematoma. Ukuran hematoma pada kelompok kontrol mengalami penambahan dimulai dari penekanan manual sampai dengan waktu 24 jam. Penambahan ukuran hematoma ini terjadi setelah penekanan mekanik, jam ke- 12, jam ke- 13, jam ke- 19, dan jam ke- 24.

Terdapatnya penambahan ukuran hematoma pada kelompok kontrol ini disebabkan oleh penekanan dengan menggunakan bantal pasir seberat $2,5 \mathrm{Kg}$ selama 6 jam. Penekanan dalam periode yang lama (lebih dari 2 jam) berisiko merusak jaringan atau menekan saraf (Shouldersodom, 2008). Waktu yang diperlukan untuk pencapaian hemostasis pada pembuluh darah yang rusak adalah 20 menit sampai 1 jam. Bekuan mulai terbentuk dalam waktu $15-30$ detik sampai $1-2$ menit. Zat-zat aktivator dari dinding pembuluh darah yang rusak dan dari trombosit, dan juga protein-protein darah yang melekat pada dinding pembuluh darah yang rusak akan mengawali proses pembekuan darah. Dalam waktu $3-6$ menit setelah pembuluh pecah, bila luka pada pembuluh tidak terlalu besar, maka seluruh bagian pembuluh yang terluka atau ujung pembuluh yang terbuka akan diisi oleh bekuan darah. Setelah 20 menit sampai satu jam, bekuan akan mengalami retraksi yang akan menutup tempat luka (Guyton \& Hall, 1997).

Selain itu, penelitian yang dilakukan oleh (Yilmaz et al., 2007) pada pasien yang menjalani prosedur invasif jantung dengan mengevaluasi penggunaan bantal pasir dan perubahan posisi pasien terhadap kejadian komplikasi vaskular dan back pain menunjukkan bahwa bantal pasir tidak efektif dalam menurunkan kejadian komplikasi vaskular dimana tidak terdapat perbedaan signifikan kejadian komplikasi vaskular pada kelompok yang menggunakan bantal pasir dengan kelompok yang tidak menggunakan bantal pasir. Penelitian lain yang dilakukan oleh Christensen et al., (1998) dan Juran et al., (1999) menunjukkan bahwa bantal pasir tidak efektif dalam menurunkan kejadian komplikasi vaskular dan perdarahan (Christensen et al., 1998 dan Juran et al., 1999).

Selama penelitian, setelah penekanan mekanik menggunakan bantal pasir seberat 2,5 $\mathrm{Kg}$ selama 6 jam ini, 2 orang subjek penelitian mengatakan bahwa terjadi kesemutan pada ekstrimitas yang menjadi area akses kateterisasi, 1 orang subjek penelitian sulit untuk menggerakkan kaki setelah 6 jam penekanan, dan 1 orang subjek penelitian kesulitan berjalan pada ektrimitas yang menjadi area akses kateterisasi pada keesokan harinya.

Pada kelompok eksperimen yang menggunakan penekanan cold pack selama 20 menit, setelah selesai penekanan tidak timbul hematoma baru pada subjek penelitian dan pada 1 orang subjek penelitian terdapat 
penambahan ukuran hematoma. Penambahan ukuran ini dilihat dari ukuran hematoma sebelumnya yang timbul akibat penekanan manual. Setelah penekanan mekanik, pasien diobservasi setiap jam selama 24 jam terhadap kejadian hematoma. Terdapat 2 orang subjek penelitian yang timbul hematoma setelah 1 jam selesai penekanan mekanik. Satu diantaranya mengalami peningkatan ukuran hematoma selama 5 jam pertama. Pada jam ke- 7 sampai dengan jam ke- 12 , terdapat 1 orang subjek penelitian dengan ukuran hematoma sama dengan sebelumnya, 1 orang hematoma timbul pada jam ke- 8,1 orang hematoma hilang pada akhir jam ke- 12, dan 1 orang terjadi penambahan ukuran hematoma. Pada jam ke13 sampai dengan jam ke- 24 , terdapat 1 orang subjek penelitian yang mengalami pengurangan ukuran hematoma pada jam ke14 dan ke- 16, 1 orang mengalami pengurangan ukuran hematoma pada jam ke14 dan hematoma hilang pada akhir jam ke18, dan 1 orang mengalami penambahan ukuran hematoma pada jam ke- 14 , ke- 20 , dan ke- 22 selanjutnya ukuran hematoma berkurang pada jam ke- 24. Pada akhir jam ke- 24 ini, kelompok eksperimen mengalami pengurangan ukuran hematoma. Ukuran hematoma pada kelompok eksperimen mengalami penambahan kemudian pengurangan dimulai dari penekanan manual sampai dengan waktu 24 jam. Penambahan ukuran hematoma ini terjadi setelah penekanan mekanik, jam ke- 1, jam ke- 2, jam ke- 3 , jam ke- 4 , jam ke- 8 , jam ke- 9 , dan jam ke- 10. Kemudian terjadi pengurangan pada jam ke- 12, jam ke- 14, jam ke- 18, jam ke- 20. Terjadi penambahan kembali pada jam ke- 22 dan berkurang pada jam ke- 24.

Terdapatnya pengurangan ukuran hematoma pada kelompok eksperimen, disebabkan oleh efek vasokonstriksi yang ditimbulkan oleh cold pack pada penekanan mekanik. Suhu dingin yang dihasilkan oleh cold pack menyebabkan konstriksi pembuluh darah arteri dan vena melalui stimulus otototot halus dalam lapisan pembuluh darah, sehingga terjadi penurunan perdarahan dan pembengkakan jaringan yang mengalami injuri. Cold pack menggunakan suhu yang dingin dalam menangani injuri. Perubahan pada suhu memiliki pengaruh pada permukaan jaringan tubuh seperti pengurangan nyeri, relaksasi otot, perubahan pembuluh darah, dan pengaruh pada jaringan konektif. (Wnorowsky, 2011).

Selain itu, penelitian yang dilakukan oleh King et al (2008) pada pasien pasca kateterisasi jantung dengan membandingkan efektivitas penekanan mekanik menggunakan bantal pasir dan cold pack dalam penanganan femoral hematoma, hasil penelitian menujukkan bahwa vasokonstriksi yang dihasilkan oleh cold pack lebih efektif dalam mengurangi kejadian hematoma dibandingkan dengan bantal pasir. Penelitian yang dilakukan oleh Karen (2009) membandingkan penekanan menggunakan bantal pasir dengan cold pack, hasil penelitian menunjukkan bahwa secara signifikan cold pack mengurangi kejadian hematoma pada pasien dibandingkan dengan bantal pasir dan pasien melaporkan bahwa penggunaan cold pack dirasakan lebih nyaman. Penelitian lain dilakukan oleh Manik (2012) pada pasien pasca kateterisasi jantung yang melihat perbedaan kejadian komplikasi vaskuler lokal dan neuropati femoral pada penekanan mekanik menggunakan cold pack selama 20 menit dengan penekanan mekanik menggunakan bantal pasir seberat $2,5 \mathrm{Kg}$ selama 1 jam. Hasil penelitian menunjukkan bahwa tidak terdapat perbedaan signifikan pada kelompok yang menggunakan bantal pasir maupun cold pack terhadap kejadian komplikasi vaskuler lokal dan neuropati femoral (Manik, 2012).

Selama penelitian, setelah penekanan mekanik menggunakan cold pack selama 20 menit ini, pasien tidak mengeluhkan timbulnya kesemutan dan kesulitan dalam menggerakkan ekstrimitas yang menjadi 
akses kateterisasi. Penggunaan cold pack ini selain mengurangi ukuran hematoma juga dirasakan lebih nyaman oleh pasien dengan berat yang lebih ringan dan penekanan yang lebih cepat.

Hasil uji statistik menunjukkan bahwa tidak terdapat perbedaan bermakna ukuran hematoma pada kelompok kontrol yang menggunakan bantal pasir seberat $2,5 \mathrm{Kg}$ selama 6 jam dengan kelompok eksperimen yang menggunakan cold pack selama 20 menit $(\rho>0,05)$ setelah penekanan manual, penekanan mekanik, dan setiap jam dalam waktu 24 jam. Tidak terdapatnya perbedaan bermakna ukuran hematoma pada kedua kelompok ini dapat dipengaruhi oleh kondisikondisi yang tidak dikontrol selama penelitian (seperti pergerakan, HOB, dan penggunaan antikoagulan) dan metoda pengukuran yang dilakukan (cara mengukur dan orang yang mengukur).

Adapun kondisi-kondisi yang tidak dikontrol pada penelitian ini adalah: 1) pergerakan subjek penelitian, dimana saat bedrest subjek penelitian dianjurkan untuk tidak menggerakkan (menekuk) ekstrimitas yang menjadi area akses kateterisasi. Pada kelompok kontrol, pergerakan pada waktu bedrest ini dapat diminimalisir dengan adanya bantal pasir diatas ekstrimitas yang menjadi area akses, sehingga pergerakan subjek penelitian terbatas. Pada kelompok eksperimen, meskipun dianjurkan untuk tidak menggerakkan ekstrimitas pada waktu bedrest, diatas ekstrimitas yang menjadi area akses tidak terdapat cold pack sehingga tanpa disadari subjek penelitian dapat menggerakkan kaki; 2) Head of bed elevation (HOB), dimana HOB pada subjek penelitian berbeda-beda namun masih didalam rentang sesuai dengan SOP; 3) Penggunaan antikoagulan selama dan setelah prosedur kateterisasi jantung seperti aspirin, clopidogrel, heparin, lovenox meningkatkan potensi untuk perdarahan secara spontan dan perluasan hematoma karena tubuh tidak dapat secara efisien memperbaiki pembuluh darah dan darah terus menerus keluar melalui area pembuluh yang rusak. Pada penelitian ini ada beberapa subjek penelitian yang menggunakan heparin, lovenox, dan aspirin setelah prosedur kateterisasi jantung.

Tidak terdapatnya perbedaan bermakna pada penelitian ini juga dapat dipengaruhi oleh: 1) Cara mengukur hematoma yang pada penelitian ini dilihat dari ukuran hematoma yang paling panjang pada area insersi femoral sheath. Dengan bentuk hematoma yang tidak simetris, pengukuran hematoma sebaiknya dilihat dari luas hematoma tersebut; 2) Pengukuran dilakukan oleh orang yang berbeda sehingga bisa menimbulkan perbedaan persepsi; 3) Tidak dilakukannya pengukuran pada saat pasien tidur sehingga ada beberapa data yang kosong dan untuk melengkapinya disesuaikan dengan ukuran hematoma sebelum pasien tidur.

Dengan tidak terdapatnya perbedaan ukuran hematoma pada kelompok yang menggunakan bantal pasir maupun cold pack ini, diharapkan cold pack bisa menjadi pilihan alat tekan mekanik dalam penanganan pasien pasca kateterisasi jantung melalui arteri femoralis. Penggunaan cold pack ini, selain lebih cepat dalam lama penekanan dan mengurangi kejadian hematoma juga dirasakan lebih nyaman oleh pasien.

\section{SIMPULAN}

Berdasarkan hasil penelitian, dapat disimpulkan bahwa terdapat penambahan ukuran hematoma dalam waktu 24 jam pada pasien pasca kateterisasi jantung dengan penekanan mekanik bantal pasir yang terjadi setelah penekanan mekanik, jam ke-12, jam ke-13, jam ke-19, dan jam ke-24. Terdapat penambahan kemudian pengurangan ukuran hematoma dalam waktu 24 jam pada pasien pasca kateterisasi jantung dengan penekanan mekanik cold pack. Penambahan ukuran hematoma terjadi setelah penekanan mekanik, jam ke-1 sampai jam ke-4, jam ke-8 sampai jam ke-10. Kemudian terjadi pengurangan ukuran hematoma terjadi pada jam e-12, jam 
ke-14, jam ke-18, dan jam ke-20. Terjadi penambahan kembali pada jam ke-22 dan berkurang pada jam ke-24. Tidak terdapat perbedaan bermakna ukuran hematoma dalam waktu 24 jam pada pasien pasca kateterisasi jantung yang menggunakan penekanan mekanik bantal pasir seberat $2,5 \mathrm{Kg}$ selama 6 jam dengan penekanan mekanik cold pack selama 20 menit.

\section{SARAN}

Berdasarkan hasil penelitian, dapat direkomendasikan bahwa cold pack dapat mencegah terjadinya hematoma seperti halnya bantal pasir, sehingga dapat dijadikan sebagai pilihan dalam penekanan mekanik untuk mencegah terjadinya perdarahan pada pasien pasca kateterisasi jantung melalui arteri femoralis. Selain mengurangi ukuran hematoma dalam waktu 24 jam, penggunaan cold pack juga dapat mengurangi beban penekanan pada ekstrimitas pasien. Berdasarkan hasil penelitian diketahui bahwa ukuran hematoma pada subjek penelitian yang mendapatkan penekanan mekanik bantal pasir memiliki kecenderungan bertambah besar dalam waktu 24 jam. Oleh sebab itu diperlukan pemantauan dan tindak lanjut untuk mengantisipasi hal yang tidak diinginkan terutama setelah pasien pulang. Salah satunya adalah mengkaji perubahan ukuran hematoma pasien sebelum pulang dan menganjurkan pasien untuk segera menghubungi rumah sakit jika ukuran hematoma bertambah besar setelah pulang ke rumah.

\section{SUMBER PUSTAKA}

Argulian, E., Patel, A. D., Abramson, J. L., Kulkarni, A., Champney, K., Palmer, S., Weintraub, W., et al. (2006). Gender Differences in Short-Term Cardiovascular Outcomes After Percutaneous Coronary Interventions. Journal of the American College of Cardiology, 48-53. doi:10.1016/j.amjcard.2006.01.048
Christensen, B, Lacarella, C., Manion, R., Bruhn-Ding, B., Meyer, S., \& Wilson, R. (1994). Sanbags do not prevent complications after catheterization. Circulation, 90, 1-205.

Christensen, BV, Manion, R., Lacarella, C., Meyer, S., Cartland, J., \& Bruhn-Ding, B. (1998). Vascular complications after angioraphy with and without the use of sandbags. Nurs Res, 47, 51-3.

Cushman, M. (2002). Effects of hormone replacement therapy and estrogen receptor modulators on markers of inflammation and coagulation. $\mathrm{Am} J$ Cardiol, 90(suppl), 7F-10F.

Direktorat Jenderal PP \& PL RI. (2009). Profil Pengendalian Penyakit \& Penyehatan Lingkungan Tahun 2008.

Grossman, W., \& Baim, D. S. (2006). Cardiac Catheterization, Angiography, and Intervention (7th Edition). (Donal S Baim, Ed.) (7th ed.). Lippincott Williams \& Wilkins.

Guyton, A. C., \& Hall, J. E. (1997). Textbook of Medical Physiology, 9th Edition. Saunders Company. Philadelphia, Pennsylvania.

Jones, T., \& Mccutcheon, H. (2002). Effectiveness of Mechanical Compression Devices in Attaining Hemostasis After Femoral Sheath Removal. American Journal Of Critical Care, 11, 155-162.

Juran, N., Rouse, C. L., Deborah, D., O’Brien, M. A., DeLuca, S. A., \& Sigmon, K. (1999). Nursing interventions to decrease bleeding at the femoral access site after percutaneous coronary intervention. American Journal Of Critical Care, 8, 303-13.

Kern, M. J., Cohen, M., Talley, J. D., Litvack, F., Serota, H., Aguirre, F., Deligonul, U., et al. (1990). Early ambulation after 5 french diagnostic cardiac catheterization: results of a multicenter trial. Journal Americal College of Cardiology, 15(7), 1475-83. 
King, N. a, Philpott, S. J., \& Leary, A. (2008). A randomized controlled trial assessing the use of compression versus vasoconstriction in the treatment of femoral hematoma occurring after percutaneous coronary intervention. Heart \& lung: the journal of critical care, 37(3), 205-10. doi:10.1016/j.hrtlng.2007.05.008

Lins, S., Guffey, D., Vanriper, S., \& Klinerogers, E. (2006). Decreasing Vascular Complications After Percutaneous Coronary Interventions: Partnering to Improve Outcomes. Critical Care Nurse, (26), 38-45.

Losordo, D., Kearney, M., Kim, E., Jekanowski, J., \& Isner, J. (1994). Variable expression of the estrogen receptor in normal and atherosclerotic coronary arteries of premenopausal women. Circulation, 89, 1501-1510.

Lundin, L., Sargent, T., \& Burke, L. (1998). Research utilization and improvement in outcomes after diagnostic cardiac catheterization. Critical care nurse, 18(5), 30-1, 34-9. Retrieved from http://www.ncbi.nlm.nih.gov/pubmed/9 934047

Miller, V., Lewis, D., \& Barber, D. (1999). Gender differences and endotheliumand platelet-derived factors in the coronary circulation. Clin Exp Pharmacol Physiol, 26, 132-136.

Manik, M. J. (2012). Perbedaan Penekanan Mekanik Bantal Pasir Durasi 1 jam dengan Cold-Pack Durasi 20 menit terhadap Insiden Komplikasi Vaskuler Lokal dan Neuropati Femoral Pasca Kateterisasi Jantung. Padjadjaran University.

Osborn, K. S., Wraa, C. E., \& Watson, A. B. (2010). Medical-surgical nursing preparation for practice volume 1 ( $\mathrm{p}$. 1129). United States of America: Pearson.

Patients Safety Advisory. (2007). Strategies to Minimize Vascular Complications following a Cardiac Catheterization.
PA-PSRS Patient Safety Advisory, 4(2), 1-8.

Rosendaal, F., Helmerhorst, F., \& Vandenbroucke, J. (2002). Female hormones and thrombosis. Arterioscler Thromb Vasc Biol, 22, 201-210.

Rubanyi, G., Johns, A., \& Kauser, K. (2002). Effect of estrogen on endothelial function and angiogenesis. Vasc Pharmacol, 38, 89-98.

Shoulders-odom, B. (2008). Management of Patients After Percutaneous Coronary Interventions. Critical Care Nurse, 28(5), 26-40.

Supriyono, M. (2008). Faktor-faktor risiko yang berpengaruh terhadap kejadian penyakit jantung koroner pada kelompok usia $<=45$ tahun. Universitas Diponegoro.

Simon, A., Bumgarner, B., Clark, K., \& Israel, S. (1998). Manual versus mechanical compression for femoral artery hemostasis after cardiac catheterization. American Journal of Critical Care, 7(4), 308.

Yilmaz, E., Gurgun, C., \& Dramali, A. (2007). Minimizing short-term complications in patients who have undergone cardiac invasive procedure: a randomized controlled trial involving position change and sandbag. Anadolu kardiyoloji dergisi: $A K D=$ the Anatolian journal of cardiology, 7, 390-6. Retrieved from http://www.ncbi.nlm.nih.gov/pubmed/1 8258546

Ying, S., Mba, R. N., Fernandez, R., Mn, R. N., Lui, M. H.-lin, Mphil, R. N., Lopez, V., et al. (2008). The clinical effectiveness of length of bed rest for patients recovering from trans-femoral diagnostic cardiac catheterisation. Int $J$ Evid Based Health, 352-390. doi:10.1111/j.1479-6988.2008.00111.x Wnorowsky. (2011). Heat and Cold Therapy. Retrieved from http://genufix.com/heat_and_cold_ther apy.htm 
Woods, S. L., Froelicher, E. S. S., Motzer, S. U., \& Bridges, E. J. (2010). Cardiac Nursing, Sixth Edition. Wolters Kluwer Health, Lippincott Williams \& Wilkins.
World Health Report. (2004). The World Health Report 2004 changing history. World Health Organization. 